\title{
Status of Customer Perspective of BSC Approach in Nepalese Commercial Banks
}

\author{
Dilip Prarajuli, PhD \\ Associate Professor, Tribhuvan University \\ Email: dilipparajuli@hotmail.com
}

\begin{abstract}
This paper explores the status of customer perspective of the BSC approach in Nepalese commercial banks and examines the comparative status of customer perspectives in three bank groups (state owned banks, private banks, and joint venture banks). The research design for the study is descriptive. The questionnaire survey has been used as a tool to gather knowledge about the BSC approach's consumer perspective (an indicator of the BSC approach). The research units are considered to be three bank classes (namely, state-owned banks, private banks, and joint venture banks). The result shows that the customer perspective as for the response per respondents is satisfactory. Especially, customer perspective in terms of better brand image, careful service, and staff's best appearance and friendliness are found good in Nepalese commercial banks.
\end{abstract}

Keywords: customer perspective, balanced scorecard, approach, commercial banks, managers

\section{Introduction}

The balanced scorecard (BSC) approach is a method that reflects on employees' contributions, from various levels of the organization, to achieve the vision and strategic goals of the business. As defined by Kaplan and Norton (1992), the balanced scorecard helps managers to look at the company from four perspectives: first the customer perspective, which gives the answer to the question "How do customers see us?". The second view is the internal viewpoint, which answers, "What do we have to excel at?". The viewpoint of creativity and learning answers, "Can we continue to improve and create value?". Finally, the financial viewpoint addresses the "How do we look at shareholders?" question (Kaplan \& Norton, 1992, 2006).

Each perspective of BSC approach determines strategic objectives that can provide the company with a competitive advantage. The core values, vision, and missions are the driving force behind the strategic objectives (Szóka, 2012). Among them customer perspective is one of the key aspects of BSC approach. Within the BSC, the customer perspective allows organizations to target the market segments they have chosen to succeed in. Correctly identifying the correct market segment an organization wants to 
address helps to develop strategies for the same organization that maximize results and, ultimately, financial rewards. The consumer perspective was not a focal point of the Balanced Scorecard in the past, as businesses assumed that product efficiency and advancement in technology were the cornerstones of business success. Nevertheless, the need to consider what customers need has been steadily emphasized by consumer behavioral patterns. Managers define business and market segments from the customer perspective, which provide some core or generic metrics of good performance from a well-developed and executed plan (Bawaneh, 2019). For the success of an organization, customers are highly important. So, businesses need to focus on this aspect of the BSC approach to enhance organizational performance.

\section{Objectives of the study}

The major objectives of the study are:

- To explore the status of customer perspective of BSC approach in Nepalese commercial banks.

- To examine the comparative status of customer perspectives in three bank groups (state owned banks, private banks, and joint venture banks).

\section{Literature Review}

The customer perspective is a recent trend of management philosophy wherein organizations are realizing the importance of customer satisfaction across various industries. Dissatisfied customers will find alternative sources to fulfill their needs, and this will result in business being lost for the organization (Roya, 2016). Pollanen and Xi (2018) reported that the customer perspective requires an organization to know how it should create value for its customers if it is to succeed. As we know, dissatisfied clients will find alternative sources to meet their needs, leading to the loss of business by the organization. Organizations have discovered the value of consumer attention and customer loyalty in sustained financial success. In spite of strong current financial results, a leading indicator of potential deterioration is a bad performance in terms of customer satisfaction. The primary overall performance metrics, from this perspective, are consumer loyalty, customer engagement, and market share, and customer profitability. An organization should evaluate metrics for the processes underlying these broad strategic objectives: delivery time, failure rates, amount of returns, warranty claims, or customer satisfaction scores.

Panicker and Seshadri (2013) also mentioned that customer satisfaction, customer complaints, the customer lost/won, and sales from a new product are the distinctive measure used under the customer perspective. Most businesses today have a corporate 
18 THE BATUK : A Peer Reviewed Journal of Interdisciplinary Studies $\quad$ Vol. $6 \quad$ Issue No. 2 July 2020 ISSN 2392-4802 mission that focuses on the customer. "To be number one in delivering value to customers" is a standard mission statement. Therefore, how a corporation operates from the viewpoint of its customers has become a priority for top management. The balanced scorecard enables managers to translate their general customer service mission statement into particular measures that represent the variables that actually matter to customers. Several customer perspective indicators of the BSC approach were established by many literature sources. However, the common indicators used in this study are customer retention, customer profitability, customer acquisition, satisfied customers, customer complaints, customer services time, market share, penetrating markets, staff to provide services to customers, skills and competence of staff, appearance and friendliness, service provided, number of new accounts opened, product/service attributes, brand image, and social/community services. This study tries to present the status of these indicators to measure the organizational orientation to its customers by considering three bank groups of Nepal.

\section{Research Methods}

Since this study aims to examine the status of the customer perspective of the BSC approach in Nepalese commercial banks; the research design for the study is descriptive in particular. The questionnaire survey is a basic research method applied to collect data regarding the customer perspective (an indicator of BSC) of the BSC approach. Three bank groups (namely, state owned banks, private banks, and joint venture banks) are considered as the study units. A total of 1015 questionnaires were distributed among the managers of these banks. The detail of the questionnaire distributed and their response rate has been depicted in Table 1 .

Table 1

Frequency of Questionnaire Responses from Three Bank Groups

\begin{tabular}{llll}
\hline Industry Type & $\begin{array}{l}\text { No of Questionnaire } \\
\text { Distributed }\end{array}$ & $\begin{array}{l}\text { No of Responses } \\
\text { Received }\end{array}$ & $\begin{array}{l}\text { Response Rate } \\
\text { (in Percentage) }\end{array}$ \\
\hline State owned banks & 105 & 78 & 74.29 \\
Private banks & 735 & 278 & 37.82 \\
Joint venture banks & 175 & 110 & 62.86 \\
\hline Total & 1015 & 466 & 46 \\
\hline
\end{tabular}

A five-point Likert-type scale from strongly disagree (1) to strongly agree (5) was used to assess the responses on customer perspective of the BSC approach. The present study has applied 16 customer-related items (as discussed in the literature review part above) to examine the overall customer relation performance of the banks. 


\section{Results and Discussions}

Customer perspective is another basic dimension of the BSC approach measuring corporate performance. This section presents the results of the data analysis.

\section{The status of customer perspective of BSC approach in Nepalese commercial banks}

This section presents the status of the customer perspective of the BSC approach in Nepalese commercial banks based on descriptive statistics.

Table 2

The Status of Customer Perspective of BSC Approach

\begin{tabular}{lll}
\hline Statements & Mean & $\begin{array}{l}\text { Std. } \\
\text { Deviation }\end{array}$ \\
\hline We have better customer retention & 3.6309 & 0.92343 \\
Customer profitability of our bank is higher & 3.6888 & 0.82941 \\
Our bank has better customer acquisition & 3.6159 & 0.85035 \\
We have more satisfied customers & 3.6373 & 0.85221 \\
We get minimum customer complaints & 3.3863 & 0.92802 \\
We provide customer services in time & 3.6781 & 0.84969 \\
We have increasing market share & 3.8262 & 0.7548 \\
We are getting success in penetrating markets & 3.6631 & 0.8087 \\
Our bank has sufficient Staff to provide services to customers & 3.4893 & 1.11726 \\
Our staff have more skills and competence & 3.7811 & 0.76997 \\
Our staff pose best appearance and friendliness & 3.8584 & 0.80409 \\
Our staff are careful to provide service & 3.882 & 0.78495 \\
Our bank has significant number of new accounts opened & 3.7854 & 0.78773 \\
Product/service attributes of our bank are distinctive & 3.4936 & 0.82499 \\
Our bank has better brand image & 3.9421 & 0.96323 \\
We offer more social/community services & 3.5794 & 0.97005 \\
\hline
\end{tabular}

Among 16 items of customer perspective, 'our bank has better brand image' has the highest mean value of 3.9421, which indicates better customer satisfaction. Similarly, the respondents have stated that their staff is careful while providing, service which represents the mean value of 3.8820, and the items, friendly and best appearance of the staff were found to be the third customer measure accepted by the respondents. Even though, all 16 customer measurements were found to be more than average. Minimum customer complaints, sufficient staff to provide service to customers, and service 
attributes of a bank as distinctive were less preferred customer perspective group. The result shows that the customer perspective as for the response per respondents is satisfactory.

\section{Comparative Status of Customer Perspectives in Three Bank Groups}

The following sections describe the items from the customer perspective as per the responses from three bank groups.

\section{Customer Retention}

Companies having more customer retention can have more competitive advantages.

From the customer perspective of the BSC approach, customer retention has been applied as the main customer performance measure. This section shows responses from the managers about the status of customer retention in their banks.

Out of 466 respondents, 246 representing the majority of the respondents agreed on better customer retention of their banks. Similarly, 60 of them have shown their strong agreement with the statement. However, 100 respondents were undecided, 48 disagreed and 12 strongly disagreed to state their bank having better customer retention. The result shows that majority of the respondents agreed on the better customer retention of their banks.

Table 3

Customer Retention

\begin{tabular}{lllllll}
\hline Type of the Banks & $\begin{array}{l}\text { Strongly } \\
\text { Disagree }\end{array}$ & Disagree & Undecided & Agree & $\begin{array}{l}\text { Strongly } \\
\text { Agree }\end{array}$ & Total \\
\hline State owned banks & 3 & 10 & 15 & 40 & 10 & 78 \\
Private banks & 8 & 33 & 59 & 142 & 36 & 278 \\
Joint venture banks & 1 & 5 & 26 & 64 & 14 & 110 \\
\hline Total & 12 & 48 & 100 & 246 & 60 & 466 \\
\hline
\end{tabular}

\section{Customer Profitability}

Customer profitability is another indicator of company performance from a customer perspective. Higher customer profitability contributes to the overall performance of a company. The respondents of survey have rated customer profitability as Table 4.

The result from the survey as per the respondents indicates that the customer profitability of their bank is higher. Out of 466 respondents 52 strongly agreed, 267 agreed with this statement. Similarly, 34 were found to have disagreed, eight strongly disagreed and 105 responded were undecided. 
Table 4

Customer Profitability

\begin{tabular}{lllllll}
\hline Type of the Banks & $\begin{array}{l}\text { Strongly } \\
\text { Disagree }\end{array}$ & Disagree & Undecided & Agree & $\begin{array}{l}\text { Strongly } \\
\text { Agree }\end{array}$ & Total \\
\hline State owned banks & 1 & 4 & 19 & 46 & 8 & 78 \\
Private banks & 6 & 29 & 57 & 155 & 31 & 278 \\
Joint venture banks & 1 & 1 & 29 & 66 & 13 & 110 \\
\hline Total & 8 & 34 & 105 & 267 & 52 & 466 \\
\hline
\end{tabular}

\section{Customer Acquisition}

More customer acquisitions mean an increase in market share which all companies deserved for. To what extent the banks of our study have acquired more customers; for the statement - better customer acquisition was presented for the rating. The responses have been presented in Table 5 .

Table 5

Customer Acquisition

\begin{tabular}{lllllll}
\hline Type of the Banks & $\begin{array}{l}\text { Strongly } \\
\text { Disagree }\end{array}$ & Disagree & Undecided & Agree & $\begin{array}{l}\text { Strongly } \\
\text { Agree }\end{array}$ & Total \\
\hline State owned banks & 0 & 8 & 26 & 36 & 8 & 78 \\
Private banks & 4 & 40 & 64 & 141 & 29 & 278 \\
Joint venture banks & 0 & 4 & 22 & 72 & 12 & 110 \\
\hline Total & 4 & 52 & 112 & 249 & 49 & 466
\end{tabular}

The result has shown that 249 out of 466 respondents have shown their agreement to the statement - our bank has better customer acquisition. Similarly, 49 of them are found to strongly agree with this statement. However, four respondents strongly disagreed with this statement. But 52 disagreed and 112 were undecided about the statement. So, banks, especially from the joint venture and private group, have better customer acquisition than the state-owned banks.

\section{Satisfied Customers}

Customer satisfaction is the ultimate motive of companies. To what extent Nepalese banks have satisfied their customers, the statement that we have more satisfied customers was applied in the survey for the rating. Table 6 reports the result. Out of 466 total respondents, 54 have shown strong agreement and 246 agreed that more satisfied customers are in their banks. The result shows that most of the banks are satisfied 
customers to improve their markets. However, 113 respondents were undecided and 49 disagreed and four respondents strongly disagreed. Similarly, private banks have applied new pricing strategies more than the joint venture banks and state-owned banks.

Table 6

Satisfied Customers

\begin{tabular}{lllllll}
\hline Type of the Banks & $\begin{array}{l}\text { Strongly } \\
\text { Disagree }\end{array}$ & Disagree & Undecided & Agree & $\begin{array}{l}\text { Strongly } \\
\text { Agree }\end{array}$ & Total \\
\hline State owned banks & 1 & 6 & 21 & 40 & 10 & 78 \\
Private banks & 2 & 36 & 74 & 136 & 30 & 278 \\
Joint venture banks & 1 & 7 & 18 & 70 & 14 & 110 \\
\hline Total & 4 & 49 & 113 & 246 & 54 & 466 \\
\hline
\end{tabular}

\section{Customer Complaints}

Customer complaints indicate deficiencies in the company's product and services offered. More customers' complaint negatively affects corporate reputation and customer retention. The opinions of bank managers about customer complaints have been presented in Table 7.

Table 7

Customer Complaints

\begin{tabular}{lllllll}
\hline Type of the Banks & $\begin{array}{l}\text { Strongly } \\
\text { Disagree }\end{array}$ & Disagree & Undecided & Agree & $\begin{array}{l}\text { Strongly } \\
\text { Agree }\end{array}$ & Total \\
\hline State owned banks & 2 & 13 & 31 & 26 & 6 & 78 \\
Private banks & 7 & 42 & 91 & 114 & 24 & 278 \\
Joint venture banks & 3 & 15 & 27 & 56 & 9 & 110 \\
\hline Total & 12 & 70 & 149 & 196 & 39 & 466 \\
\hline
\end{tabular}

Among, 466 respondents 196 respondents agreed on minimum customer complaints of their banks. Similarly, 39 of them have shown their strong agreement with the statement. However, 149 respondent's undecided, 70 disagreed and 12 strongly disagreed to state their bank having minimum customer complaints. The result shows that majority of the respondents confirmed that there were minimum customer complaints of their banks.

\section{Customer Services Time}

Customers seek products and services in time. The companies' that can deliver services in time get more advantage in customer retention and satisfaction. 
Table 8

Customer Services Time

\begin{tabular}{lllllll}
\hline Type of the Banks & $\begin{array}{l}\text { Strongly } \\
\text { Disagree }\end{array}$ & Disagree & Undecided & Agree & $\begin{array}{l}\text { Strongly } \\
\text { Agree }\end{array}$ & Total \\
\hline State owned banks & 0 & 10 & 20 & 40 & 8 & 78 \\
Private banks & 5 & 23 & 57 & 157 & 36 & 278 \\
Joint venture banks & 1 & 10 & 25 & 62 & 12 & 110 \\
\hline Total & 6 & 43 & 102 & 259 & 56 & 466 \\
\hline
\end{tabular}

The result (Table 8) from the survey indicates that most of the respondents have replied that their banks have provided customer services on time. Out of 466 respondents, 56 strongly agreed, 259 agreed with this statement. Similarly, 43 disagreed, six strongly disagreed and 102 were undecided about this statement.

\section{Market Share}

Increasing market share shows more customer acquisition and retention. To what extent the commercial banks are successful in increasing their market share to indicate this, the statement - we have increasing market share -was included in the questionnaire survey. Table 9 reports the result. Out of 466 respondents, 69 have shown strong agreement and 275 agreed on increasing market share in their banks. The result shows that most of the banks are increasing market share to improve customer relations. However, 96 respondents were undecided and 24 disagreed and only two respondents strongly disagreed.

Table 9

Market Share

\begin{tabular}{lllllll}
\hline Type of the Banks & $\begin{array}{l}\text { Strongly } \\
\text { Disagree }\end{array}$ & Disagree & Undecided & Agree & $\begin{array}{l}\text { Strongly } \\
\text { Agree }\end{array}$ & Total \\
\hline State owned banks & 1 & 10 & 9 & 46 & 12 & 78 \\
Private banks & 1 & 12 & 61 & 169 & 35 & 278 \\
Joint venture banks & 0 & 2 & 26 & 60 & 22 & 110 \\
\hline Total & 2 & 24 & 96 & 275 & 69 & 466 \\
\hline
\end{tabular}

\section{Penetrating Markets}

Penetrating a specific market shows the capacity of market development. In the survey, the respondents were asked to rate the extent to which their bank is getting success in penetrating markets. Table 10 shows the responses received. 
24 THE BATUK : A Peer Reviewed Journal of Interdisciplinary Studies $\quad$ Vol. $6 \quad$ Issue No. $2 \quad$ July 2020 ISSN 2392-4802

The result has shown that 237 out of 466 respondents have shown their agreement to the statement - getting success in penetrating markets of the banks. Similarly, 57 of them are found to have strongly agreed with this statement. However, only one respondent strongly disagreed but 40 disagreed and 131 were undecided about the statement.

Table 10

Penetrating Markets

\begin{tabular}{lllllll}
\hline Type of the Banks & $\begin{array}{l}\text { Strongly } \\
\text { Disagree }\end{array}$ & Disagree & Undecided & Agree & $\begin{array}{l}\text { Strongly } \\
\text { Agree }\end{array}$ & Total \\
\hline State owned banks & 0 & 9 & 27 & 35 & 7 & 78 \\
Private banks & 1 & 22 & 76 & 142 & 37 & 278 \\
Joint venture banks & 0 & 9 & 28 & 60 & 13 & 110 \\
\hline Total & 1 & 40 & 131 & 237 & 57 & 466 \\
\hline
\end{tabular}

\section{Staff to Provide Services to Customers}

To provide better and timely services to the customer it is essential to have the right number of sufficient staff. The response of managers on the statement-our bank has sufficient staff to provide services to customers is presented in Table 11. Out of 466 respondents, 220 respondents agreed that sufficient staffs are needed to provide services to customers of their banks. Similarly, 70 of them have shown their strong agreement with the statement. However, 74 respondents were undecided, 72 disagreed and 30 strongly disagreed to state their bank having sufficient staff to provide services to customers. The result shows that most of the respondents are convinced that sufficient staff is essential to provide services to customers of their banks.

Table 11

Staffs to Provide Services to Customers

\begin{tabular}{lllllll}
\hline Type of the Banks & $\begin{array}{l}\text { Strongly } \\
\text { Disagree }\end{array}$ & Disagree & Undecided & Agree & $\begin{array}{l}\text { Strongly } \\
\text { Agree }\end{array}$ & Total \\
\hline State owned banks & 1 & 7 & 5 & 41 & 24 & 78 \\
Private banks & 27 & 45 & 44 & 127 & 35 & 278 \\
Joint venture banks & 2 & 20 & 25 & 52 & 11 & 110 \\
\hline Total & 30 & 72 & 74 & 220 & 70 & 466 \\
\hline
\end{tabular}

\section{Skills and Competence of Staff}

The staff who deals with customers must have the necessary skills and competence.

Organizations invest more resources for the development of necessary skills and 
competence. To examine the current state of skills and competence of banking and staff the statement - our staff have more skills and competence - was applied to the survey. Table 12 shows the result.

Table 12

Skills and Competence of Staff

\begin{tabular}{lllllll}
\hline Type of the Banks & $\begin{array}{l}\text { Strongly } \\
\text { Disagree }\end{array}$ & Disagree & Undecided & Agree & $\begin{array}{l}\text { Strongly } \\
\text { Agree }\end{array}$ & Total \\
\hline State owned banks & 0 & 8 & 20 & 43 & 7 & 78 \\
Private banks & 2 & 17 & 56 & 167 & 36 & 278 \\
Joint venture banks & 0 & 4 & 25 & 61 & 20 & 110 \\
\hline Total & 2 & 29 & 101 & 271 & 63 & 466 \\
\hline
\end{tabular}

The result from the survey indicates that most of the respondents have replied that their bank staff has more skills and competence. Out of 466 respondents, 63 strongly agreed, 271 agreed with this statement. Similarly, 101 were found to be undecided, 29 disagreed and only two strongly disagreed.

\section{Appearance and Friendliness}

One of the major factors that play a vital role in customer satisfaction is the external appearance and behavioral patterns such as the friendliness of the staff. As derived from the managers' responses regarding the best appearance and friendly behavior of the staff have been shown in Table 13.

Table 13

Staff Appearance and Friendliness

\begin{tabular}{lllllll}
\hline Type of the Banks & $\begin{array}{l}\text { Strongly } \\
\text { Disagree }\end{array}$ & Disagree & Undecided & Agree & $\begin{array}{l}\text { Strongly } \\
\text { Agree }\end{array}$ & Total \\
\hline State owned banks & 3 & 5 & 23 & 38 & 9 & 78 \\
Private banks & 2 & 17 & 46 & 166 & 47 & 278 \\
Joint venture banks & 0 & 4 & 11 & 70 & 25 & 110 \\
\hline Total & 5 & 26 & 80 & 274 & 81 & 466 \\
\hline
\end{tabular}

In connection with 466 total respondents, 81 have shown strong agreement and 274 agreed on the importance of appearance and friendliness in their banks. The result shows that most of the banks are adopting the best appearance and friendliness to improve their financial conditions. However, 80 respondents were undecided and 26 disagreed and five respondents strongly disagreed. Similarly, the joint venture banks have employed staff 


\section{THE BATUK : A Peer Reviewed Journal of Interdisciplinary Studies $\quad$ Vol. 6 Issue No. 2 July 2020 ISSN 2392-4802}

compared to the staff employed by private banks and the state banks' best appearance and friendliness.

\section{Service Provided}

To examine the opinions of the respondents about their staff being careful to provide services, the statement - our staff are careful to provide services - was included in the survey. Table 14 shows the results received from the respondents.

Table 14

Careful to Provide Service

\begin{tabular}{lllllll}
\hline Type of the Banks & $\begin{array}{l}\text { Strongly } \\
\text { Disagree }\end{array}$ & Disagree & Undecided & Agree & $\begin{array}{l}\text { Strongly } \\
\text { Agree }\end{array}$ & Total \\
\hline State owned banks & 2 & 5 & 16 & 47 & 8 & 78 \\
Private banks & 3 & 16 & 41 & 164 & 54 & 278 \\
Joint venture banks & 0 & 4 & 12 & 77 & 17 & 110 \\
\hline Total & 5 & 25 & 69 & 288 & 79 & 466 \\
\hline
\end{tabular}

The result has shown that 288 out of 466 respondents agree to the statement - our staff is careful to provide service of the banks. Similarly, 79 of them strongly agreed with this statement. However, five respondents strongly disagreed with this statement. But 25 disagreed and 69 were undecided about this statement. Therefore, the staffs of private banks and joint venture banks are more careful than the staff of state-owned banks regarding the service they provide to their customers'.

\section{Number of New Accounts Opened}

In the case of banking service, the number of new accounts opens shows more customer acquisition. Table 15 provides the result of the opinions from the respondents on the statement - out the bank has a significant number of new accounts opened.

Table 15

Number of New Accounts Opened

\begin{tabular}{lllllll}
\hline Type of the Banks & $\begin{array}{l}\text { Strongly } \\
\text { Disagree }\end{array}$ & Disagree & Undecided & Agree & $\begin{array}{l}\text { Strongly } \\
\text { Agree }\end{array}$ & Total \\
\hline State owned banks & 1 & 6 & 10 & 41 & 20 & 78 \\
Private banks & 1 & 20 & 69 & 155 & 33 & 278 \\
Joint venture banks & 0 & 4 & 24 & 66 & 16 & 110 \\
\hline Total & 2 & 30 & 103 & 262 & 69 & 466 \\
\hline
\end{tabular}


Out of 466 respondents, 262 representing the majority of the respondents agreed on the significant number of new accounts opened in their banks. Similarly, 69 of them have shown their strong agreement with the statement. However, 103 respondents were undecided, 30 disagreed and two strongly disagreed with the statement.

\section{Product/Service Attributes}

The companies offering unique attributes of their product and services can have more customer satisfaction the statement - product/ service attributes of our bank are distinctive - has been rated by the respondents in Table 16.

Table 16

Product/Service Attributes

\begin{tabular}{lllllll}
\hline Type of the Banks & $\begin{array}{l}\text { Strongly } \\
\text { Disagree }\end{array}$ & Disagree & Undecided & Agree & $\begin{array}{l}\text { Strongly } \\
\text { Agree }\end{array}$ & Total \\
\hline State owned banks & 0 & 9 & 28 & 39 & 2 & 78 \\
Private banks & 5 & 41 & 81 & 128 & 23 & 278 \\
Joint venture banks & 0 & 3 & 38 & 62 & 7 & 110 \\
\hline Total & 5 & 53 & 147 & 229 & 32 & 466 \\
\hline
\end{tabular}

The result from the survey indicates that most of the respondents have replied that their banks have been providing products/services distinctive from others. Out of 466 respondents, 32 strongly agreed and 229 agreed with this statement. Similarly, 53 were found to have disagreed, 147 remained undecided and five strongly disagreed with the statement.

\section{Brand Image}

A better brand image provides significant advantages in the acquisition and retention of more customers. To examine the brand image of the banks, the respondents replied to the statement that their bank has a better brand image. The responses are shown in Table 17.

Out of 466 total respondents, 135 have shown strong agreement and 223 agreed that the bank has a better brand image in their banks. The result shows that most of the banks have a better brand image to improve their financial conditions. However, 68 respondents were undecided and 26 disagreed and 14 respondents strongly disagreed. Similarly, the state-owned banks have a better brand image than that of the private banks and joint venture banks. 
Table 17

Brand Image

\begin{tabular}{lrrrrrr}
\hline Type of the Banks & $\begin{array}{c}\text { Strongly } \\
\text { Disagree }\end{array}$ & Disagree & Undecided & Agree & $\begin{array}{l}\text { Strongly } \\
\text { Agree }\end{array}$ & Total \\
\hline State owned banks & 0 & 0 & 8 & 37 & 33 & 78 \\
Private banks & 14 & 25 & 46 & 140 & 53 & 278 \\
Joint venture banks & 0 & 1 & 14 & 46 & 49 & 110 \\
\hline Total & 14 & 26 & 68 & 223 & 135 & 466 \\
\hline
\end{tabular}

\section{Social/Community Services}

The involvement in more social and community welfare services enhance the goodwill of the company and gain more attraction attractions for the customer. The respondents were asked to rate this opinion and their evaluation has been shown in Table 18.

Table 18

Social/Community Services

\begin{tabular}{lrrrrrr}
\hline Type of the Banks & $\begin{array}{c}\text { Strongly } \\
\text { Disagree }\end{array}$ & Disagree & Undecided & Agree & $\begin{array}{l}\text { Strongly } \\
\text { Agree }\end{array}$ & Total \\
\hline State owned banks & 1 & 2 & 8 & 46 & 21 & 78 \\
Private banks & 13 & 44 & 62 & 126 & 33 & 278 \\
Joint venture banks & 0 & 8 & 42 & 48 & 12 & 110 \\
\hline Total & 14 & 54 & 112 & 220 & 66 & 466 \\
\hline
\end{tabular}

The result has shown that a total of 220 from 466 respondents have shown their agreement to the statement - we offer more social/community services of the banks. Similarly, 66 of them are found to have strongly agreed with this statement. However, 14 respondents strongly disagreed with this statement. But 54 disagreed and 112 undecided about the statement. Therefore, especially state-owned banks are engaged more in social/community services than the joint venture banks and private banks.

\section{Conclusion}

As generated by Kaplan and Norton (1992), the BSC principle borders on the theory that management should concentrate not only on the financial aspects of the business, but also on the customer, internal processes and creativity, and aspects of learning. The idea aims to give managers a holistic view of the business and helps them to concentrate on the organization's crucial areas, thus moving the plan forward. It also helps to 
communicate and execute the policy of an organization (Chimtengo, Mkandawire, \& Hanif, 2017).

As a key aspect of the BSC approach, the customer perspective is concerned with evaluating the corporate performance applying different scales related to customer acquisition, satisfaction retention, and so on. The results show that among 16 items of customer perspective, two items stating that their bank has better brand image has been the most preferred dimension with a 3.9421 score. Similarly, the item that states staff with careful service providing got 3.8820 scores and another item stating the staff's best appearance and friendliness got 3.8584 scores from the analysis, it has been found that the 16 items under this dimension have risen above the average, this indicates a good customer relation performance of the banks and group mean of this dimension is 3.6836. It shows satisfactory customer relations of the banks. The conclusion of the study is consistent with the conclusion drawn in Hoque (2014), Roya (2016), Pollanen and Xi (2018), Panicker and Seshadri (2013), Szóka (2012), and Bawaneh (2019). Thus, to get success organizations need to obtain and use information from customers to develop a strategy that will meet customer needs and implement that strategy by being responsive to customer needs and wants.

\section{References}

Bawaneh, S. (2019). Using the Balanced Scorecard Perspectives to Measure the Performance of Manufacturing Companies in Jordan. Academy of Accounting and Financial Studies Journal, 23(5).

Chimtengo, S., Mkandawire, K., \& Hanif, R. (2017). An evaluation of performance using the balanced scorecard model for the University of Malawi's Polytechnic. African Journal of Business Management, 11(4), 84-93.

Hoque, Z. (2014). 20 years of studies on the balanced scorecard: Trends, accomplishments, gaps and opportunities for future research. The British accounting review, 46(1), 33-59.

Kaplan, R.S., \& Norton, D. P. (2006). How to implement a new strategy without disrupting your organization. Harvard Business Review (March), 100-109.

Kaplan, R. S., \& Norton, D. P. (1992). The balanced scorecard: Measures that drive performance. Harvard Business Review, 70(1), 71-79.

Kaplan, R. S., \& Norton, D. P. (1996). Using the balanced scorecard as a strategic management system. Harvard Business Review, 74(1), 75-85.

Panicker, S., \& Seshadri, V. (2013). Devising a balanced scorecard to determine Standard Chartered Bank's Performance: A case study. International Journal of Business Research and Development, 2(2), 35-42. 
30 THE BATUK : A Peer Reviewed Journal of Interdisciplinary Studies $\quad$ Vol. $6 \quad$ Issue No. 2 July 2020 ISSN 2392-4802

Panicker, S., \& Seshadri, V. (2013). Devising a balanced scorecard to determine Standard Chartered Bank's Performance: A case study. International Journal of Business Research and Development, 2(2), 35-42.

Pollanen, R. M., \& Xi, K. K. (2018). The effects of using balanced scorecard measures in executive compensation on organizational performance. International Journal of Business, Accounting, \& Finance, 12(1), 1-16.

Roya, R. (2016). Application of balanced scorecard (BSC) in evaluating the performance of health care providers. International Journal on Recent and Innovation Trends in Computing and Communication, 4(3), 322 - 327.

Szóka, K. (2012). The Significance of the Balanced Scorecard financial perspective Presented through the example of the AMOENA Medical Devices Trade and Provider Ltd. Journal of International Studies, 5(1), 84-94.

Turban, E., Leidner, D., McLean, E., \& Wetherbe, J. (2008). Information Technology for Management. John Wiley and Sons. 